\title{
Late Pleistocene owls (Aves, Strigiformes) from Ecuador, with the description of a new species
}

\author{
Gastón E. Lo Coco ${ }^{1,2}$ • Federico L. Agnolín ${ }^{1,2,4}$ • José Luis Román Carrión ${ }^{3}$
}

Received: 20 October 2019 / Revised: 21 December 2019 / Accepted: 3 February 2020

(c) Deutsche Ornithologen-Gesellschaft e.V. 2020

\begin{abstract}
The fossil record of owls of the families Strigidae and Tytonidae in South America is poor. The aim of the present contribution is to report for the first time fossil Strigiformes from Riobamba Canton, at Chimborazo province, in Ecuador. The specimens come from a large owl burrow from Late Pleistocene beds of the Cangagua Formation. We report the finding of fossil record of Athene cunicularia and Tyto aff. T. furcata and the first fossil record of Glaucidium from Ecuador. Further, a giant species of the genus Asio is described. The specimen constitutes the largest known asionine owl, being approximately of the size of a big female of Bubo virginianus. Based on prey content at the fossil burrow, it is possible that the new Asio species predated on the other owls. If this inference is correct, it may represent the first evidence indicating intra-ordinal predation in the fossil record.
\end{abstract}

Keywords Strigidae $\cdot$ Tytonidae $\cdot$ Glaucidium $\cdot$ Asio $\cdot$ Late Pleistocene $\cdot$ Ecuador

\section{Zusammenfassung}

Eulenarten (Aves, Strigiformes) des Jungpleistozäns aus Ecuador, mit Beschreibung einer neuen Art

Es gibt wenige Fossilfunde von Eulenarten der Familie Strigidae und Tytonidae in Südamerika. Das Ziel dieses Beitrags ist es, zum ersten Mal über fossile Strigiformes aus dem Kanton Riobamba der Provinz Chimborazo, Ecuador zu berichten. Die Exemplare stammen aus einer großen Eulenhöhle aus den Schichten des Jungpleistozäns der Cangahua Formation. Wir berichten über die Fossilfunde von Athene cunicularia und Tyto aff. T. furcata sowie über den ersten Fossilfund von Glaucidium in Ecuador. Weiterhin beschreiben wir eine riesige Art der Gattung Asio. Dieses Exemplar stellt die größte bekannte Eulenart dieser Gattung dar, die in etwa die Größe vergleichbar mit einem weiblichen Virginiauhu Bubo virginianus hat. Basierend auf Beutefunde aus der fossilen Höhle, lässt sich vermuten, dass sich die neue Asio-Art von anderen Eulenarten ernährte. Falls diese Folgerung richtig sein sollte, könnte dies der erste fossile Nachweis für eine Prädation innerhalb der eigenen Ordnung sein.

Communicated by J. T. Lifjeld.

Gastón E. Lo Coco

gastonlococo@gmail.com

1 Laboratorio de Anatomía Comparada y Evolución de los Vertebrados, Museo Argentino de Ciencias Naturales Bernardino Rivadavia, Av. Ángel Gallardo 470, C1405DJR Buenos Aires, Argentina

2 Concejo Nacional de Investigaciones Científicas y Técnicas, Buenos Aires, Argentina

3 Departamento de Biología, Facultad de Ciencias, Escuela Politécnica Nacional, calle Ladrón de Guevara E11-253, Quito, Ecuador

4 Fundación de Historia Natural "Félix de Azara", Hidalgo 775, C1405BDB Buenos Aires, Argentina

\section{Introduction}

The fossil reports of owls of the families Strigidae and Tytonidae in South America is extremely poor. The earliest reports come from the early Miocene of Patagonia, Argentina (Chiappe 1991; Tambussi and Noriega 1996) but remain undescribed. Remaining records are restricted to neospecies found in early-middle Pleistocene of Argentina (Cenizo 2006; Cenizo and De Los Reyes 2008) and Late Pleistocene beds of Argentina, Brazil, and Peru (Winge 1887; Ameghino 1891; Brodkorb 1971; Campbell 1979; Tonni 1983; Guérin et al. 1993; Cenizo et al. 2015).

From Ecuador, the fossil record of birds is still incomplete and most analyses are restricted to the abundant 
avifauna from the Late Pleistocene tar pits at La Carolina (Spillman 1942; Hoffstetter 1952; Campbell 1976), close to the Pacific coast.

\section{Study area}

The fossil site is located in the Andes, at the south of Riobamba Canton, at Chimborazo province, Ecuador (Fig. 1). Its ravines are part of the Chambo River basin and are known as Quebrada Chalán $\left(01^{\circ} 46^{\prime} 32.3^{\prime \prime} \mathrm{S} / 78^{\circ} 37^{\prime} 41.1^{\prime \prime}\right.$ W; Moreno Cárdenas and Román-Carrión 2017). Today, the area is encompassed within a seasonal shrub ecosystem at $2800 \mathrm{~m}$ above sea level (Josse et al. 2009), surrounded by field crops belonging to local populations.

The aim of the present contribution is to report for the first time fossil Strigiformes from the Ecuadorian Andes and to describe a new large owl of the genus Asio coming from Late Pleistocene beds.

\section{Materials and methods}

The fossils we described here were collected by Alejandro Mesías and José Luis Román-Carrión between the years 2009 and 2012, in a small site we interpreted as being a fossil owl burrow (Moreno Cárdenas and Román-Carrión 2017). The fossil assemblage of Quebrada Chalán comprises six specimens of different Strigiformes and several skeletal elements of birds and mammals, including shrews (genus Cryptotis, Moreno Cárdenas and Román-Carrión 2017), rabbits, and cricetid rodents. We interpreted these as being prey items of the owner of the owl burrow, including the small strigids and tytonids reported here.

Specimens come from Cangagua Formation loess beds, mainly composed by hard volcanic ashes of eolic origin, assigned to the Late Pleistocene (Sauer 1950; Fig. 1), and based on faunal composition, belonging to the Lujanian South American Mammalian Age/Stage (Sánchez et al. 2013; Moreno Cárdenas and Román-Carrión 2017).

Anatomical nomenclature follows Baumel and Witmer (1993). Bone description follows Campbell (2013).

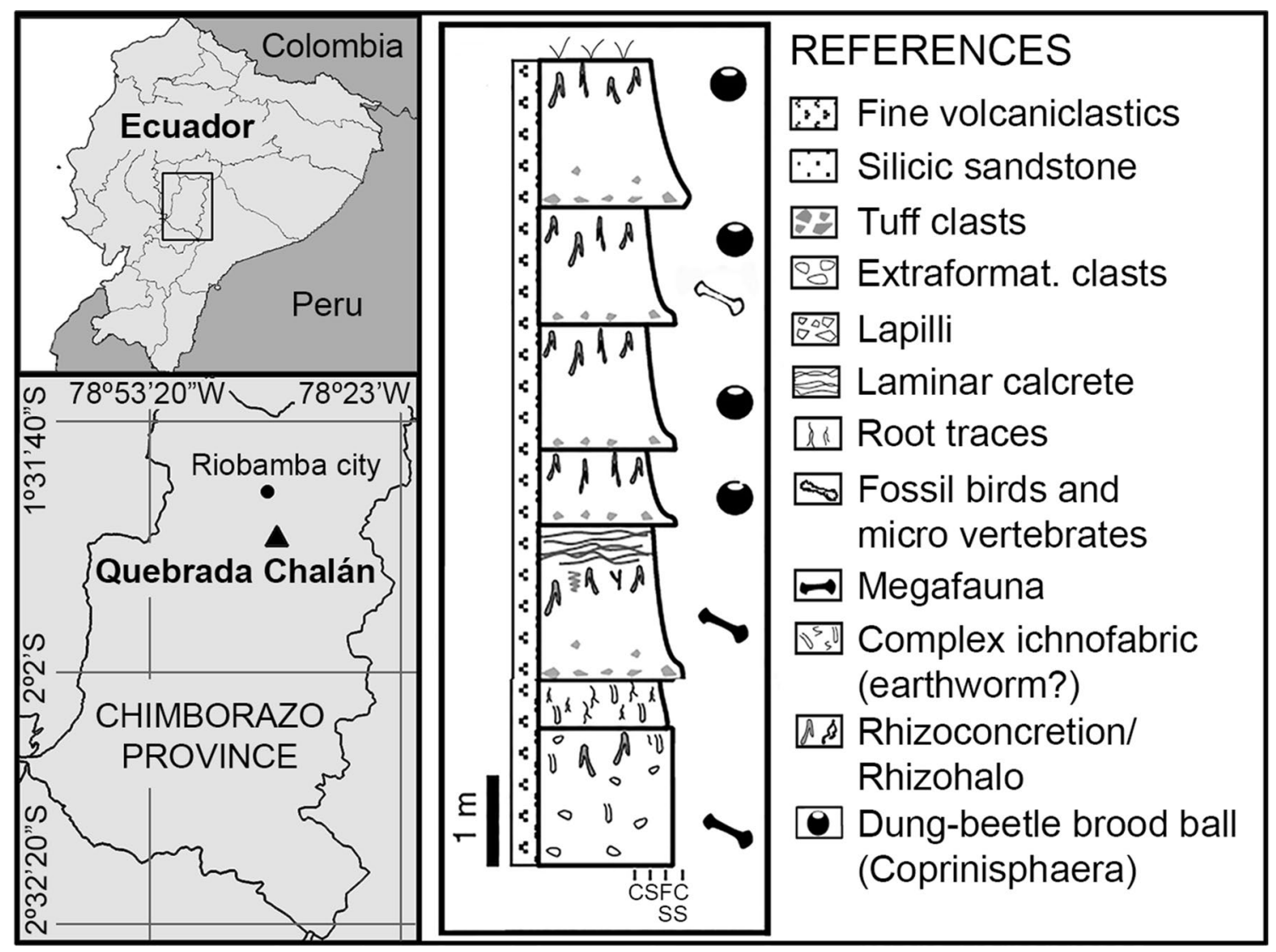

Fig. 1 Schematic map showing Late Pleistocene fossil location of Quebrada Chalán, Riobamba Canton, Chimborazo province, Ecuador and the stratigraphic profile at Quebrada Chalán 


\section{Institutional abbreviations}

MACN Museo Argentino de Ciencias Naturales Bernardino Rivadavia, Buenos Aires, Argentina; EPNV Colección de Paleontología, Escuela Politécnica Nacional, Quito, Ecuador.

\section{Systematic paleontology}

Strigiformes Wagler, 1830

Tytonidae Ridgway, 1914

Tyto Billberg, 1828

Tyto aff. T. furcata
Fig. 2 Tyto aff. T. furcata (EPNV, no. 6365; a-e) distal right tarsometatarsus in (a) cranial, (b) lateral, (c) caudal, (d) medial and (e) distal views. Athene cunicularia (EPNV, no. 6366 ; f-h) distal right tarsometatarsus in (f) cranial, (g) caudal and (h) distal views. Glaucidium sp. proximal right (EPNV, no. 6363; i-m) and proximal left (EPNV, no. 6364; $\mathbf{n}-\mathbf{r})$ tarsometatarsus in $(\mathbf{i}, \mathbf{n})$ cranial, (j, o) lateral, (k, p) caudal, $(\mathbf{l}, \mathbf{q})$ medial and $(\mathbf{m}, \mathbf{r})$ proximal views. Scale bars $1 \mathrm{~cm}$

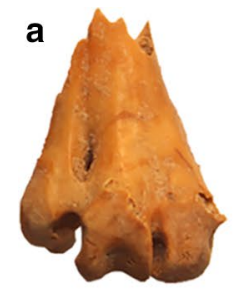

b
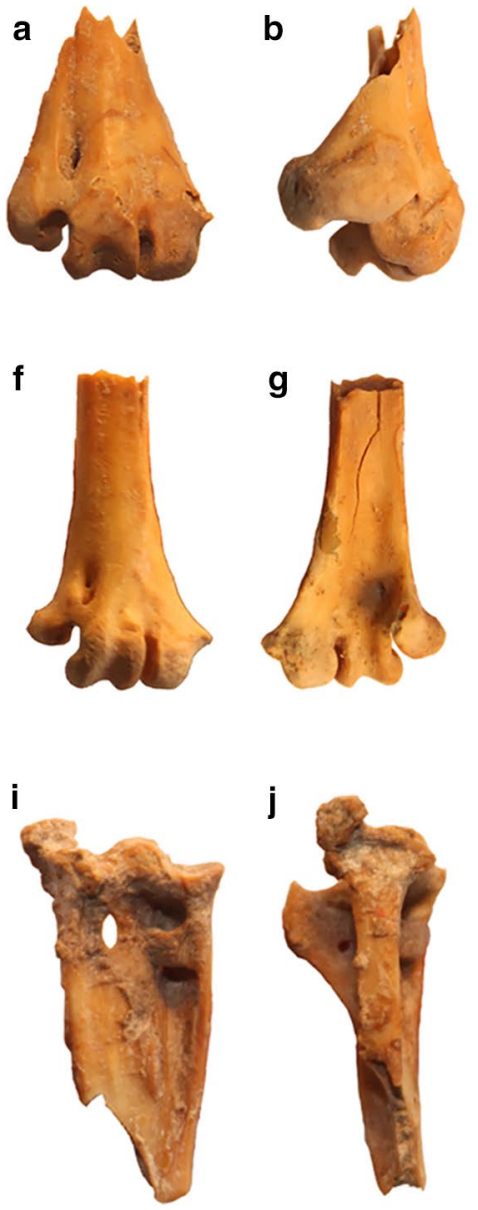

n
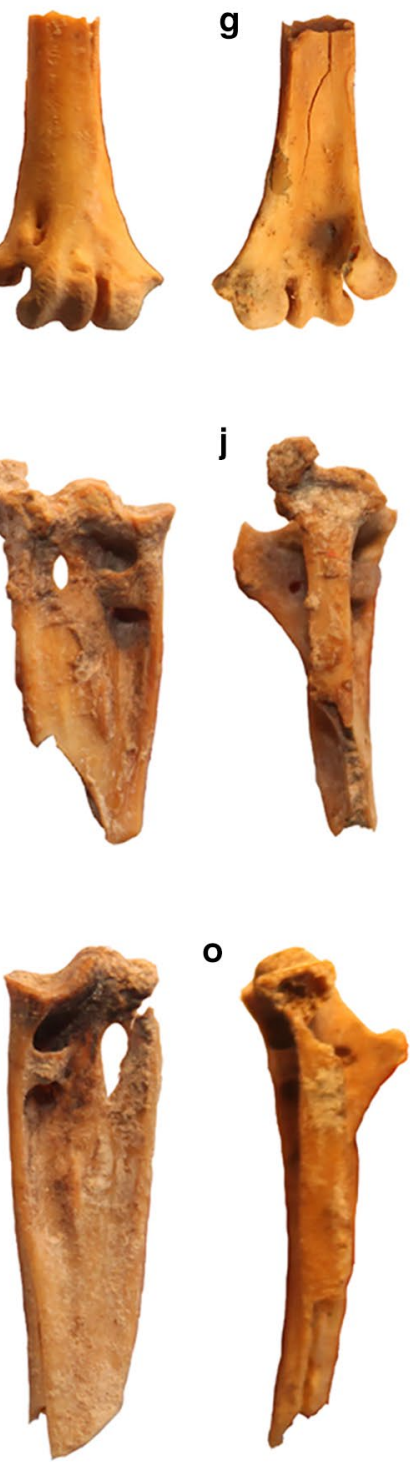

0

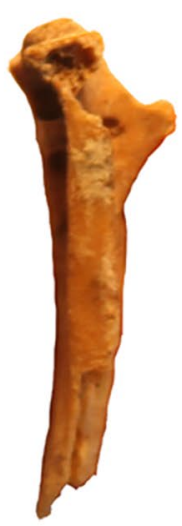

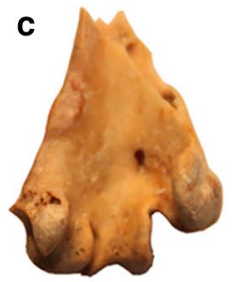
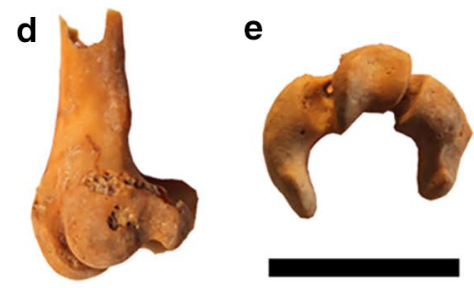

h

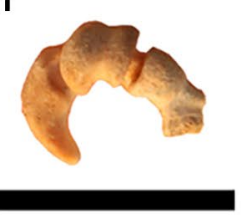

j $\quad$ k
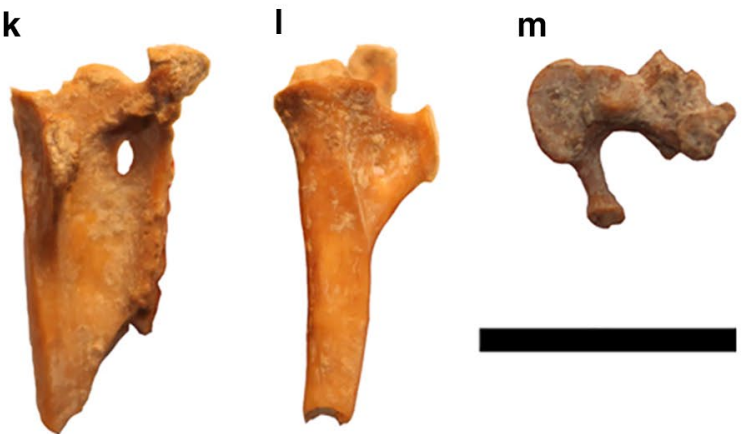

p

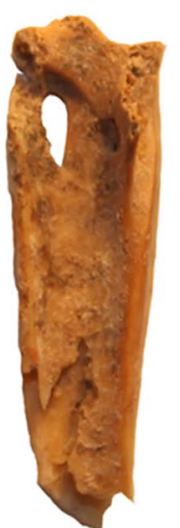

q

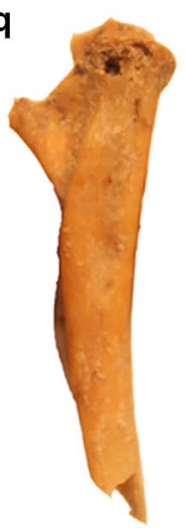

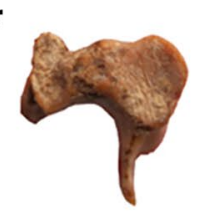


Referred specimen Distal end of right tarsometatarsus (EPNV, no. 6365; Fig. 2a-e). The specimen shows weathering and breakage on its surface, being typical of stomach acid-derived abrasion of Strigiformes (Dodson and Wexlar 1979).

Remarks The specimen can be referred to T. furcata on the basis of the following combination of characters: tarsometatarsus with mediolaterally narrow shaft, slightly divergent distal trochleae, reduced notch between trochleae II and III, narrow second distal trochlea, craniodorsal portion of outer rim of trochlea III flattened, massive and poorly elevated trochlea IV, ventral margin of trochlea IV strongly indented (Ford 1967; Mourer-Chauviré 1987; Suárez and Olson 2015). Further, the size of tarsometatarsus falls within the range of T. furcata (Arredondo 1972a, b; Rich and Bohaska 1976; Suárez and Olson 2015). Because different species previously included within T. alba (i.e., T. furcata, T. alba, T. javanica) are not distinguishable on the basis of postcranial elements, we here identify the remains from Ecuador as Tyto aff. T. furcata based on gross morphological similarity and by geographical criterion, since in South America the only living and extinct species of the genus Tyto is T. furcata (reported as T. alba by previous authors; König and Weick 2008; Nijman and Aliabadian 2013).

Oldest fossils of the species come from the early-middle Pleistocene of Buenos Aires province, Argentina (Cenizo and De Los Reyes 2008). By the Late Pleistocene the species is reported from Brazil, Peru and Ecuador (Winge 1887; Campbell 1976, 1979).

Strigidae Leach, 1820

Athene Boie, 1822

Athene cunicularia (Molina 1782)

Referred specimen Distal end of right tarsometatarsus (EPNV, no. 6366; Fig. 2f-h). This specimen shows signs of weathering and breakage on its external surface, being evidence of digestive abrasion by Strigiformes (Dodson and Wexlar 1979).

Remarks The following combination of characters indicates that specimen belongs to genus Athene: small size and elongate metatarsal shaft, presence of second foramen vasculare distale, distally extended trochlea metatarsi III, wider and more prominent lateral part of the trochlea metatarsal III than its medial part, medial groove of trochlea metatarsal III deep, and distal trochlea IV relatively small, very proximally located and laterally oriented, with its caudal flange poorly caudally and medially extended (Ford 1967; Olson and Hilgartner 1982; Pavia and Mourer-Chauviré 2002; Guerra et al. 2012). Its size falls within the range of A. cunicularia and the narrow metatarsal shaft that is well excavated caudally, small and poorly divergent distal trochleae, blunt lateral margin of trochlea III in caudal view that is more caudally extended than the medial one indicates that fossil specimen belong to this taxon (Pavia and Mourer-Chauviré 2002; Cenizo 2006; Guerra et al. 2012).

Fossils of this species in South America are reported from the Late Pleistocene of La Carolina, Santa Elena, Ecuador (Campbell 1976), and in Argentina, from Late Pleistocene to Early Holocene of Buenos Aires province (Ameghino 1891; Tonni 1983); an indeterminate probably new, but still unpublished species is known from the Middle Pleistocene of coastal Buenos Aires province (Cenizo 2006).

\section{Glaucidium Boie, 1826 Glaucidium sp.}

Referred material Proximal end of right tarsometatarsus (EPNV, no. 6363; Fig. 2i-m); proximal end of left tarsometatarsus (EPNV, no. 6364; Fig. 2n-r), belonging to different individuals. Both tarsometatarsi show signs of weathering and breakage on its external surface, including a broadened foramen vasculare proximale, being probably evidence of digestive abrasion (Dodson and Wexlar 1979).

Remarks The specimens may be referred to the genus Glaucidium on the basis of the following combination of characters: shaft, in cranial view, bowing markedly medial, cranial face distal and lateral to extensor groove shallowly excavated, with craniolateral corner of shaft forming an acute and prominent ridge, in caudal view deeply and broadly excavated proximally between hypotarsal crests, extensor groove forming a shallow sulcus in the craniolateral side of intercotylar prominence, strongly proximally extended and subrectangular-shaped crista lateralis hypotarsi, and relatively poorly developed crista medialis hypotarsi (Campbell and Bochenski 2013).

The complex taxonomy of the genus Glaucidium in America resulted in the recognition of a large number of species, but authors are far from reaching a consensus about its taxonomic composition (Enríquez et al. 2015). Because of the large number of known species, that are indistinguishable osteologically, the specimens here reported are not identified to the specific level. Nevertheless, the size of specimens falls within the range of the widespread South American species G. nanum (Campbell and Bochenski 2013), being much smaller than other strigids as Athene and Tyto.

The fossil record of Glaucidium in South America is restricted to $G$. brasilianum from the Late Pleistocene of Brazil (Winge 1887). Present finding constitutes the first record for the genus in Ecuador. 
Asioninae Vigors, 1825

Asio Brisson, 1760

Asio ecuadoriensis nov. sp.

Holotype Distal end of right tibiotarsus (EPNV, no. 6367; Fig. 3a-e); nearly complete right tarsometatarsus belonging to the same individual (EPNV, no. 6368; Figs. 3f-k and 4a). Both specimens lack abrasion or stomach acid-derived weathering.

Diagnosis Species of the genus Asio, probably representing the largest known asionine (Fig. 4) showing the following unique combination of characters (autapomorphies marked by an asterisk): tarsometatarsus with robust shaft (similar to A. priscus), well-developed and proximally extended crista lateralis hypotarsi*, proximal end of crista lateralis hypotarsi forming a well-developed subtriangular surface in lateral view (similar to A. flammeus), strongly concave lateral margin of shaft (similar to A. flammeus), crista plantaris medialis well developed and strongly convex (similar to A. priscus), calcaneal ridge proximodistally low and transversally thick (similar to A. priscus), proximally oriented calcaneal ridge (similar to A. flammeus), strongly distally divergent middle trochlear rings* (subparallel in A. flammeus and A. priscus), and tibiotarsus with proximal part of
Fig. 3 Asio ecuadoriensis nov. sp. distal right tibiotarsus (EPNV, no. 6367; a-e) and right tarsometatarsus (EPNV, no. $6368 ; \mathbf{f}-\mathbf{k})$ in $(\mathbf{a}, \mathbf{f})$ cranial, (b, g) lateral, $(\mathbf{c}, \mathbf{h})$ caudal, $(\mathbf{d}, \mathbf{i})$ medial and (j) proximal and $(\mathbf{e}$, k) distal views. Scale bar $1 \mathrm{~cm}$
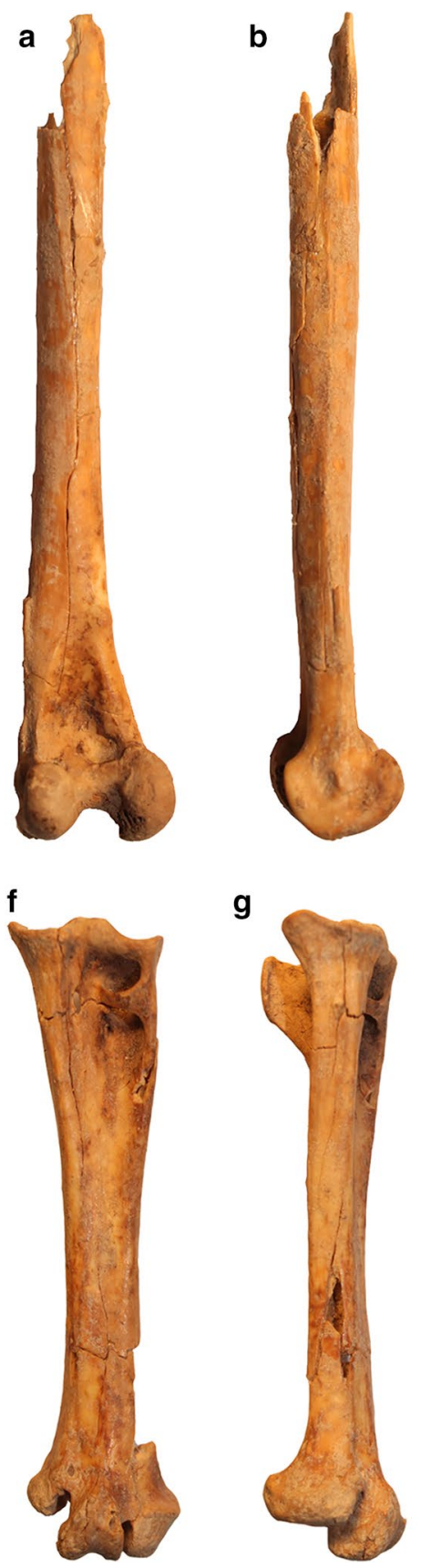

g

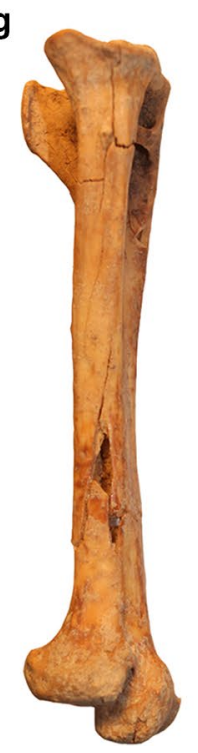

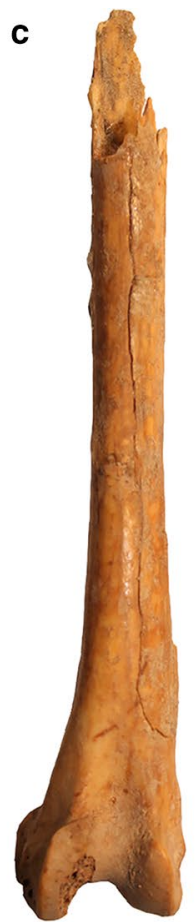

h

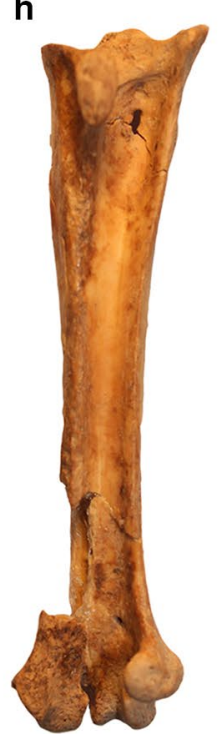

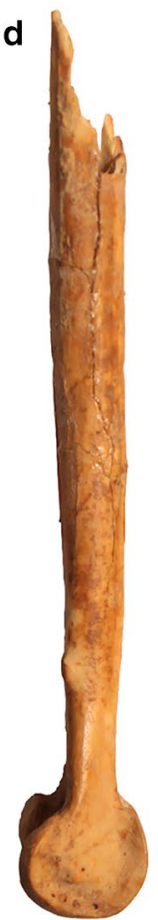

e

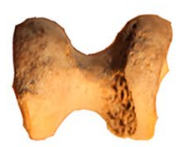

i

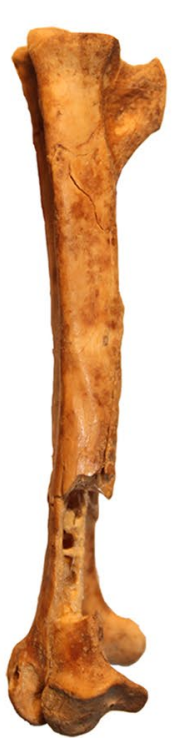

j
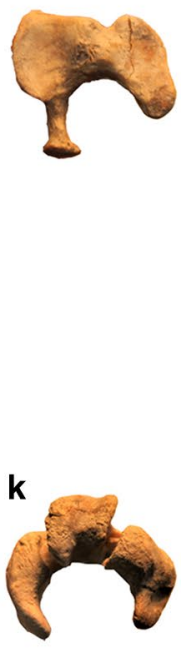
Fig. 4 Right tarsometatarsus of (a) Asio ecuadoriensis nov. sp. (EPNV, no. 6368), (b) Asio flammeus (MACN, no. 2317), (c) Pseudoscops clamator (MACN, no.1404), (d) Asio stygius (MACN, no. 1421), and (e) Bubo virginianus (MACN, no. 54,505$)$, in cranial views. Scale bar $1 \mathrm{~cm}$
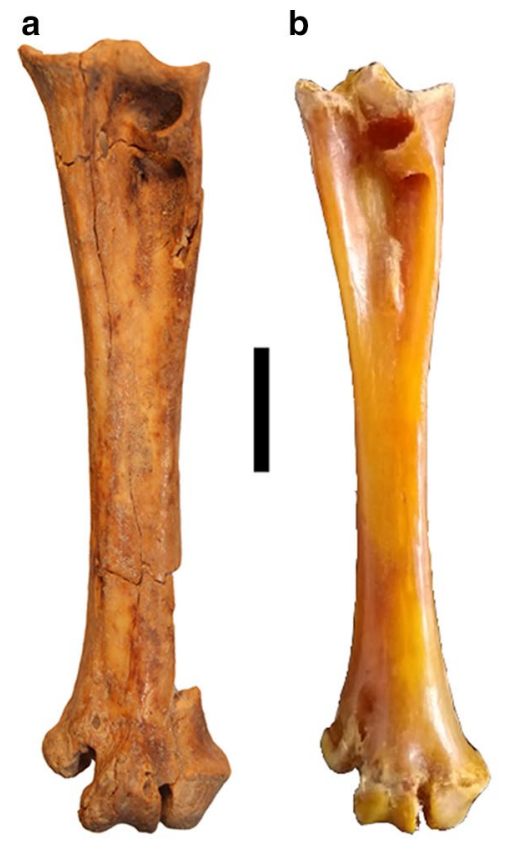
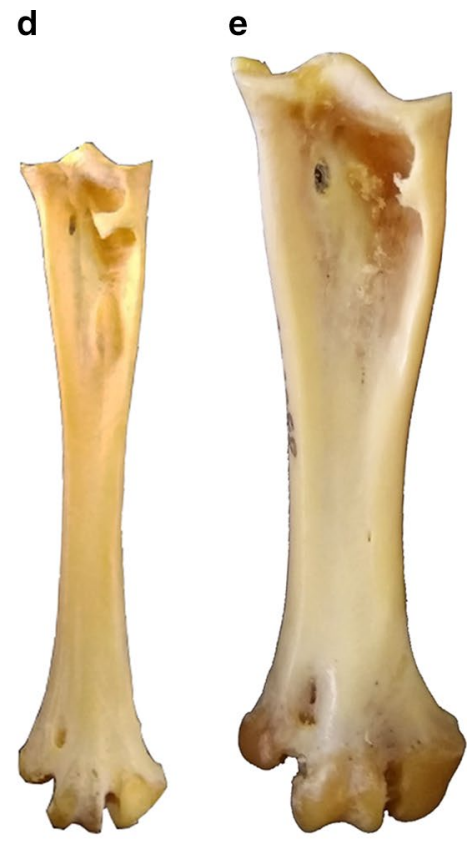

the trochlea cartilaginous tibialis lacking a transverse ridge in caudal view* (presence of a ridge in known Asio species; Pavia et al. 2015).

Among the largest South American species, the tarsometatarsus of A. ecuadoriensis sp. nov. are clearly larger than Asio flammeus, A. stygius and Pseudoscops clamator, are more robust than A. flammeus and A. stygius, and slenderer than Bubo virginianus.

Etymology ecuadoriensis, for República del Ecuador, honoring the country that yielded the remains of the new species.

Description Asio ecuadoriensis sp. nov. had legs the size of a big female Bubo virginianus (see "measurements"). The right tibiotarsus is incompletely preserved, only the distal end is present (Fig. 3a-e). The shaft is transversely narrow and expands distally. The condyles are robust and cranially extended, resulting in a wide U-shaped incisura intercondylaris. The lateral condyle extends distally, not laterally, and is sub-parallel to the lateral edge of shaft. The medial condyle extends distally and medially. The incisura intercondylaris is well developed, deep and transversely wide.

The right tarsometatarsus is nearly complete, only some portions of the shaft are missing (Fig. 3f-k). The bone is relatively robust, with the crista lateralis hypotarsi well developed laterocaudally. The eminentia intercotylaris is wide and the cotylae lateralis is more rounded than the elliptical cotylae medialis. The crista medialis hypotarsi is positioned medially with a broad and elliptical facies plantaris. Between the crista medialis hypotarsi and the lateral edge, there is a subtriangular and broad groove. The sulcus flexorius is broad along all its extension. The distal trochlea III extends slightly distally than trochlea II. The outer rim of trochlea III extends farther caudally and slightly laterally.

Measurements Tibiotarsus: total length (as preserved) $81.6 \mathrm{~mm}$; width at mid-shaft (as preserved) $6.1 \mathrm{~mm}$; distal width $14.4 \mathrm{~mm}$; condylus lateralis width $11.1 \mathrm{~mm}$; Condylus medialis width $11.4 \mathrm{~mm}$. Tarsometatarsus: total length $65.2 \mathrm{~mm}$; proximal width $16.2 \mathrm{~mm}$; length of hypotarsus $6.6 \mathrm{~mm}$; width of hypotarsus $3.5 \mathrm{~mm}$; minimum shaft width $7.2 \mathrm{~mm}$; distal width $16.3 \mathrm{~mm}$.

Remarks The specimen here reported is referrable to asionines because of the following combination of characters: crista lateralis hypotarsi not laterally flaring, broad arcus extensorius, scar for muscle tibialis cranialis externally displaced, outer rim of middle trochlea much longer than the inner rim (especially in caudal view), outer and inner rims of middle trochlea that are subequally cranially extended, and smoothly curved articular surface of distal trochlea IV in lateral view (Ford 1967; Mlíkovský 1998). The tibiotarsus resembles Asio in the presence of a deep excavation of shaft cranio-proximal to distal trochleae, in having a shallow rounded depression caudally above the distal condyles, narrow shaft, expanded and distally extended distal attachment for fibula, and tuberculum retinaculi musculi fibularis prominent (Howard 1933; Campbell 2013; Pavia et al. 2015). In addition, in spite that $A$. ecuadoriensis sp. nov. has a distal width of tarsometatarsus similar to Pseudoscops, it differs because the distance between the trochleae is proportionately narrow and the sulcus extensorius poorly distally 
extended (Ford 1967). Nesasio shows several distinctive features, but its strong robustness clearly distinguishes it from Asio (Olson 1995).

Although A. ecuadoriensis sp. nov. is similar to B. virginianus in size (the only living species of the genus in South America; Fig. 4), it clearly differs from this species and the extinct Pleistocene Antillean species B. osvaldoi in notably slender proportions, lacking a transversely expanded and massive proximal end and a poorly defined and feebly defined scar for the muscle tibialis cranialis (Arredondo and Olson 1994).

Despite there being very few specimens of A. ecuadoriensis $\mathrm{sp}$. nov., the length and robustness of the holotype indicate that it had longer and more robust legs than any other extant or extinct asionine (Fig. 4; Campbell 2013). In addition, the greater width of the intercondylar groove of tibiotarsus is indicative of a notably robust, powerful leg (Campbell 2013). In fact, the robustness of the hindlimb may be correlated with thick and deep muscle scars, which are related to the strength of grip and ability to resist the stresses applied by a struggling prey (Weick and Brown 1980; Fergusson-Lee and Christie 2001; Worthy and Holdaway 2002).

Fossil asionine owls in South America are represented by Pseudoscops clamator, Asio stygius, and Speotyto cunicularia from the Late Pleistocene of Venezuela (Wetmore 1935), Brazil (Winge 1887), and Ecuador (Campbell 1976). Present finding constitutes the first extinct asionine taxon described for South America.

As indicated above, the fossil owl remains of Tyto, Athene and Glaucidium show breakage and weathering, typical of stomach acid-derived abrasion of Strigiformes (Dodson and Wexlar 1979). This indicates that, as occurs with mammals coming from the site, they would be prey items of the owl that is the owner of the burrow (detailed taphonomical and taxonomical analysis of the site is being carried out by one of the authors; JLRC). The large size of A. ecuadoriensis sp. nov., as well as the absence of acid-derived weathering of the bones, may constitute indirect evidence that this taxon is the owner of the burrow. It is worthy to mention that in the fossil record it is very common to find bones of the owner of the nest on its ancient burrows (Pardiñas 1999).

\section{Discussion}

Arredondo and Olson (1994) determined that the Pleistocene of North and Central America show a higher diversity of large owls than nowadays. This is particularly true for the Antilles, among which giant Barn owls and gigantic strigids were highly diversified (Arredondo 1976, 1982; Arredondo and Olson 1994; Suárez and Olson 2015). In the same sense,
Olson (1984) reported a giant owl from the Late Pleistocene of North America and Campbell (2013) described in detail the large asionine Asio priscus from California (Howard 1933). This is in concordance with the high diversity of giant condors, caracarines, and diurnal raptorial birds reported in the Pleistocene of North and South America (Jones et al. 2015). This diversification may be linked to the aridification of the climate with accompanying expansion of open habitat enabling an increase in the abundance potential food resources (Jacobs et al. 1999).

By the Latest Pleistocene-Early Holocene, the extinction of gigantic mammals is considered as one of the main factors that prompted the disappearance of several genera and species of giant scavengers and raptors (Tyrberg 2008; Jones et al. 2015). The highest proportion of extinct birds in the Pleistocene includes raptorial birds of large size (Tyrberg 2008). However, in spite that scavenger raptorial birds may have been deeply affected by extinction of the giant mammals that constituted their main food resource, the extinction of giant non-scavenger raptors and owls lacks a reliable explanation.

It is probable, as suggested by Pavia (2008), that selective impact that occurred in the Pleistocene extinction eradicated the larger raptorial species more easily, so that the more specialized taxa went extinct first. These taxa should have lower population densities than the smaller ones and usually have higher extinction rates (Peters 1983). This may be also applied to raptorial birds of South and Central America, where a large number of large to gigantic owls, including Asio ecuadoriensis sp. nov., disappeared.

Previously reported prey items of Asio ecuadoriensis sp. nov. include rodents, shrews and rabbits (Moreno Cárdenas and Román-Carrión 2017). Present contribution adds diverse owls (e.g., Tyto, Athene, Glaucidium) that very probably formed part of the diet of A. ecuadoriensis sp. nov. This may indicate that this taxon is probably an owl-specialized predator. It is well known that owls usually prey on raptors (e.g., Real and Mañosa 1990; Rohner and Doyle 1992; Tella and Mañosa 1993; Serrano 2000), but predation on owls by owls is uncommon and remains poorly explored in the literature (Mikkola 1976; Donázar 1989; Serrano 2000; Lourenço and Rabaça 2006). If correctly interpreted, the present contribution may constitute the first fossil evidence of owl being killed by owls.

Acknowledgements We thank Alejandro Mesías and Pablo Lara for their help during fieldwork. We thank Edith Montalvo (Ornithology curator, EPNV) and Yolanda Davis (Ornithology curator, MACN) and Sergio Bogan (Ornithology curator, Fundación de Historia Natural Félix de Azara) for access to osteological collections under their care. We are grateful to Fernando Novas for his support during the conduction of the present study. 


\section{Compliance with ethical standards}

Conflict of interest The authors declare that they have no conflict of interest.

\section{References}

Ameghino F (1891) Enumeración de las aves fósiles de la República Argentina. Rev Argent Hist Nat 1:441-453

Arredondo O (1972a) Nueva especie de ave fósil (Strigiformes: Tytonidae) del Pleistoceno superior de Cuba. Bol Soc Venez Cienc Nat 29:415-431

Arredondo O (1972b) Especie nueva de lechuza gigante (Strigiformes: Tytonidae) del Pleistoceno cubano. Bol Soc Venez Cienc Nat 30:129-140

Arredondo O (1982) Los Strigiformes fósiles del Pleistoceno Cubano. Bol Soc Venez Cienc Nat 140:33-55

Arredondo O, Olson SL (1994) A new species of owl of the genus Bubo from the Pleistocene of Cuba (Aves, Strigiformes). Proc Biol Soc Wash 107:436-444

Arredondo O (1976) The great predatory birds of the Pleistocene of Cuba. In: Olson SL (ed) Collected papers in Avian Paleontology honoring the 90th birthday of Alexander Wetmore Smithson Contrib Paleobiol, 27th edn. Smithsonian Institution Press, Washington, pp 169-187

Baumel JJ, Witmer LM (1993) Osteologia. In: Baumel JJ, King AS, Breazile JE, Evans HE, Vanden Berge JC (eds) Handbook of avian anatomy: Nomina Anatomica Avium. Nuttall Ornithological Club, Cambridge, pp 45-132

Brodkorb P (1971) Catalogue of fossil birds. Part 4 (Columbiformes through Piciformes). Bull Fla State Mus Biol Sci 15:163-266

Campbell KE (1976) The Late Pleistocene Avifauna of La Carolina, southwestern Ecuador. Smithson Contrib Paleobiol 27:155-168

Campbell KE (1979) The non-passerine Pleistocene avifauna of the Talara Tar Seeps, northwestern Peru. R Ont Mus Life Sci Contrib 118(1):203

Campbell KE Jr, Bochenski ZM (2013) Two new late Pleistocene miniature owls from Rancho La Brea, California. Acta Palaeontol Pol 58:707-721

Campbell KE Jr (2013) Revisiting Asio priscus, an extinct eared owl of the California Channel Islands. In: Göhlich UB, Kroh A (eds) Proceedings 8th international meeting of the Society of Avian Paleontology and Evolution. Paleornithological research 2013. Verlag Naturhistorisches Museum, Wien, pp 185-194

Cenizo MM (2006) Un nuevo estrígido (Strigiformes, Aves) para el Plioceno Tardío-Pleistoceno Medio de la provincia de Buenos Aires, Argentina Con algunos comentarios sobre la morfología tarsal del género Athene Boie, 1822. $9^{\circ}$ Congreso Argentino de Paleontología y Bioestratigrafía. Academia Nacional de Ciencias, Córdoba, p 100

Cenizo MM, de Los Reyes LM (2008) Primeros registros de Tyto alba (Scopoli, 1769) (Strigiformes, Aves) en el Pleistoceno MedioTardío de la provincia de Buenos Aires (Argentina) y sus implicancias tafonómicas. Rev Mus Argent Cienc Nat 10:199-209

Cenizo MM, Agnolin FL, Pomi LH (2015) A new Pleistocene bird assemblage from the southern Pampas (Buenos Aires, Argentina). Palaeogeogr, Palaeoclimatol, Palaeoecol 420:65-81

Chiappe LM (1991) Fossil birds from the Miocene Pinturas Formation of southern Argentina. J Vertebr Paleontol 11:21A-22A

Dodson P, Wexlar D (1979) Taphonomic investigations of owl pellets. Paleobiology 5(3):275-284
Donázar JA (1989) Variaciones geográficas y estacionales en la alimentación del Búho Real (Bubo bubo) en Navarra. Ardeola 36(1):25-39

Enríquez PL, Eisermann K, Motta-Junior JC, Mikkola H (2015) Una revisión de la Taxonomía y Sistemática de los búhos Neotropicales. In: Enríquez PL (ed) Los Búhos Neotropicales: Diversidad y Conservación. ECOSUR, México, pp 29-38

Fergusson-Lee J, Christie DA (2001) Raptors of the world. Houghton Mifflin Company, Boston

Ford NL (1967) A systematic study of the owls based on comparative osteology. Dissertation, University of Michigan

Guérin C, Hugueney M, Mourer-Chauviré C, Faure M (1993) Paléoenvironnement Pléistocene dans l'aire archéologique de Sao Raimundo Nonato (Piaui, Brésil): apport des mammiféres et des oiseaux. Doc Lab Géol Lyon 125:187-202

Guerra C, Bover P, Alcover JA (2012) A new species of extinct little owl from the Pleistocene of Mallorca (Balearic Islands). J Ornithol 153:347-354

Hoffstetter R (1952) Les mammifères pléistocènes de la République de l’Équateur. Mém Soc Géol Fr 66:1-391

Howard H (1933) A new species of owl from the Pleistocene of Rancho La Brea, California. Condor 35:66-69

Jacobs BF, Kingston JD, Jacobs LL (1999) The origin of grass-dominated ecosystems. Ann Mo Bot Gard 86:590-643

Jones WW, Cenizo MM, Agnolin FL, Rinderknecht A, Blanco RE (2015) The largest known falconid. N Jahrb Geol Paläontol 277(3):361-372

Josse C, Cuesta F, Navarro G, Barrena V, Cabrera E, Chacón-Moreno E, Ferreira W, Peralvo M, Saito J, Tovar A (2009) Ecosistemas de los Andes del Norte y Centrales. Bolivia, Colombia, Ecuador, Perú y Venezuela. Secretaría General de la Comunidad Andina, Programa Regional ECOBONA-Intercooperation, CONDESANProyecto Páramo Andino, Programa BioAndes, EcoCiencia, Nature Serve, IAvH, LTA-UNALM, ICAE-ULA, CDC-UNALM, RUMBOL SRL. Lima, Peru

König C, Weick F (2008) Owls of the World, 2nd edn. Yale University Press, New Haven

Lourenço R, Rabaça J (2006) Intraguild predation by eagle owls in Europe. Airo 16:63-68

Mikkola H (1976) Owls killing and killed by other owls and raptors in Europe. Br Birds 69:144-154

Mlíkovský J (1998) Two new owls (Aves: Strigidae) from the early Miocene of the Czech Republic, with comments on the fossil history of the subfamily Striginae. Buteo 10:5-22

Moreno Cárdenas PA, Román-Carrión JL (2017) Musarañas del género Cryptotis (Eulipotyphla: Soricidae) en el Pleistoceno Tardío de los Andes Ecuatorianos. Bol Soc Geol Mex 69(2):421-432

Mourer-Chauviré C (1987) Les Strigiformes (Aves) des Phosphorites du Quercy (France): systématique, biostratigraphie et paléobiogéographie. Doc Lab Géol Lyon 99:89-135

Nijman V, Aliabadian M (2013) DNA barcoding as a tool for elucidating species delineation in wide-ranging species as illustrated by owls (Tytonidae and Strigidae). Zool Sci 30:1005-1009

Olson SL, Hilgartner W (1982) Fossil and Subfossil Birds from the Bahamas. In: Olson SL (ed) Fossil Vertebrates from the Bahamas. Smithson Contrib Paleobiol, 48th edn. Smithsonian Institution Press, Washington, pp 22-56

Olson SL (1984) A very large enigmatic owl (Aves: Strigidae) from the late Pleistocene at Ladds, Georgia. In: Genoways HH, Dawson MR (eds) Contributions in quaternary vertebrate paleontology: a volume in memorial to John E. Guilday, vol 8. Carnegie Museum of Natural History Special Publication, pp 44-46

Olson SL (1995) The genera of owls in the Asioninae. Bull Brit Ornithol Club 115:35-39

Pardiñas UFJ (1999) Tafonomía de microvertebrados en yacimientos arquelógicos de Patagonia (Argentina). Arqueol 9:265-339 
Pavia M (2008) The evolution dynamics of the Strigiformes in the Mediterranean Islands with the description of Aegolius martae $\mathrm{n}$. sp. (Aves, Strigidae). Quat Int 182(1):80-89

Pavia M, Mourer-Cauviré C (2002) An overview of the genus Athene in the Pleistocene of the Mediterranean Islands, with the description of Athene trinacriae n. sp. (Aves: Strigidae). In: Zhou Z, Zhang F (eds) Proceedings of the 5th symposium of the Society of Avian Paleontology and Evolution. China Science Press, Beijing, pp 13-27

Pavia M, Manegold A, Haarhoff P (2015) Early Pliocene owls from Langebaanweg, South Africa, with first evidence of the genus Athene south of the Sahara and the description of a new species of Tyto. Acta Palaeontol Pol 60(4):815-828

Peters RH (1983) The ecological implications of body size. Cambridge University Press, Cambridge

Real J, Mañosa S (1990) Eagle Owl (Bubo bubo) predation on juvenile Bonelli's Eagles (Hieraaetus fasciatus). J Raptor Res 24(3):69-71

Rich PV, Bohaska D (1976) The world's oldest owl: a new strigiform from the Paleocene of southwestern Colorado. In: Olson SL (ed) Collected papers in avian paleontology honoring the 90th birthday of Alexander Wetmore. Smithson Contrib Paleobiol 27:87-93

Rohner C, Doyle FI (1992) Food-stressed great horned owl kills adult goshawk: exceptional observation or community process? J Raptor Res 26(4):261-263

Sánchez MV, Genise JF, Bellosi ES, Román-Carrión JL, Cantil LF (2013) Dung beetle brood balls from Pleistocene highland palaeosols of Andean Ecuador: a reassessment of Sauer's Coprinisphaera and their palaeoenvironments. Palaeogeogr, Palaeoclimatol, Palaeoecol 386:257-274

Sauer W (1950) Contribuciones para el Conocimiento del Cuaternario en el Ecuador. Anales Univ Central Quito 77:327-364

Serrano D (2000) Relationship between raptors and rabbits in the diet of eagle owls in southwestern Europe: competition removal or food stress? J Raptor Res 34(4):305-310
Spillmann F (1942) Contribución al conocimiento de fósiles nuevos de la avifauna Ecuatoriana en el Pleistoceno de Santa Elena. Proc Eighth Am Sci Congr 4:375-389

Suárez W, Olson SL (2015) Systematics and distribution of the giant fossil Barn owls of the West Indies (Aves: Strigiformes: Tytonidae). Zootaxa 4020(3):533-553

Tambussi C, Noriega JI (1996) Summary of the Avian fossil record from southern South America. In: Arratia G (ed) Contributions of southern South America to Vertebrate Paleontology. Müncher Geowiss Abh, 30:245-264

Tella JL, Mañosa S (1993) Eagle Owl predation on Egyptian Vulture and Northern Goshawk: possible effect of a decrease in European rabbit availability. J Raptor Res 27(2):111-112

Tonni EP (1983) Aves de un sitio arqueológico del área interserrana de la provincia de Buenos Aires. Ameghiniana 20(1-2):3-10

Tyrberg T (2008) The Late Pleistocene continental avian extinctionan evaluation of the fossil evidence. Oryctos 7:249-269

Weick F, Brown L (1980) Birds of prey of the world: a colored guide to identification of all the diurnal species order Falconiformes. Verlag Paul Parey, Hamburg

Wetmore A (1935) Pre-Columbian bird remains from Venezuela Auk 52(3):328-329

Winge H (1887) Jordfundne og nulevende Gnavere (Rodentia) fra Lagoa Santa, Minas Geraes, Brasilien. E Museo Lundii 1:1-200

Worthy TH, Holdaway RN (2002) The lost world of the moa: prehistoric life of New Zealand. Indiana University Press, Bloomington

Publisher's Note Springer Nature remains neutral with regard to jurisdictional claims in published maps and institutional affiliations. 